\title{
Effect of Cr Addition on the Phase Equilibria and Oxidation Behavior of $\mathrm{NbSi}_{2}$
}

\author{
Nobuaki Sekido ${ }^{1, * 1}$, Ryoma Aizawa ${ }^{2, * 2}$ and Shunkichi Ueno ${ }^{2}$ \\ ${ }^{1}$ Graduate School of Engineering, Tohoku University, Sendai 980-8579, Japan \\ ${ }^{2}$ College of Engineering, Nihon University, Koriyama 963-8642, Japan
}

\begin{abstract}
Effect of $\mathrm{Cr}$ addition on the phase equilibria and oxidation behavior of $\mathrm{NbSi}_{2}$ was investigated. Although the crystal structures of $\mathrm{NbSi}_{2}$ and $\mathrm{CrSi}_{2}$ are both $\mathrm{C} 40$, they form separated ranges of homogeneities in the $\mathrm{Nb}-\mathrm{Cr}-\mathrm{Si}$ ternary system. The vertical section passing through the $\mathrm{NbSi} \mathrm{i}_{2}$ and $\mathrm{CrSi}_{2}$ binary edges were experimentally determined. A binary $\mathrm{NbSi}_{2}$ alloy exhibited poor oxidation resistance, showing pest-like behavior upon cyclic oxidation at temperatures from 800 to $1200^{\circ} \mathrm{C}$. On the other hand, $\mathrm{Cr}$ addition significantly improved the oxidation resistance of $\mathrm{NbSi}_{2}$. The oxide layers that developed on the $\mathrm{Nb}-\mathrm{Cr}-\mathrm{Si}$ ternary alloys consisted of $\mathrm{NbCrO}_{4}, \mathrm{Cr}_{2} \mathrm{O}_{3}$, and $\mathrm{SiO}_{2}$, and the formation of $\mathrm{Cr} \mathrm{O}_{3}$ and $\mathrm{NbCrO}_{4}$ suppresses the $\mathrm{Nb}_{2} \mathrm{O}_{5}$ formation, and thereby suppresses the pest-like behavior of the binary $\mathrm{NbSi}_{2}$ alloy. However large Cr additions that exceed the solubility limit of $\mathrm{NbSi}_{2}$ should not be suitable, because $\mathrm{NbSi}_{2} / \mathrm{CrSi}_{2}$ alloys were susceptible to spalling and disintegration of the oxide scales upon cyclic oxidation. [doi:10.2320/matertrans.MB201809]
\end{abstract}

(Received November 29, 2018; Accepted February 25, 2019; Published April 25, 2019)

Keywords: $\mathrm{Nb}$ disilicides, oxidation, phase diagram evaluation, $\mathrm{NbCrO}_{4}$

\section{Introduction}

Last decades, $\mathrm{Nb}-\mathrm{Si}$ alloys have been considered as candidate materials for alternative high temperature structural materials with superior properties to Ni based superalloys. ${ }^{1,2)}$ The $\mathrm{Nb}-\mathrm{Si}$ alloys have been shown to exhibit a good combination of high temperature strength and room temperature toughness through a suitable microstructure control., ${ }^{3,4)}$ However, one of the biggest challenges faced by $\mathrm{Nb}-\mathrm{Si}$ alloys is low oxidation resistance. ${ }^{5,6}$ Therefore, application of coating on $\mathrm{Nb}-\mathrm{Si}$ alloys would be inevitable, coupled with significant improvement in the oxidation resistance of the $\mathrm{Nb}-\mathrm{Si}$ alloy substrates.

Some refractory metal disilicides, such as $\mathrm{MoSi}_{2}$ and $\mathrm{WSi}_{2}$, are known to exhibit outstanding oxidation resistance at high temperatures, and thus disilicides would be promising for coating application. At the same time, selection of coating materials that are chemically compatible to the substrates is beneficial, because reactions between coating and substrate can be suppressed. From these perspectives, $\mathrm{NbSi}_{2}$ based multiphase coatings are worth pursuing, since they have potential opportunity to be in equilibrium with $\mathrm{Nb}-\mathrm{Si}$ alloy substrates. However, contrary to $\mathrm{MoSi}_{2}, \mathrm{NbSi}_{2}$ exhibits poor oxidation resistance at temperature above $800^{\circ} \mathrm{C} .{ }^{7}$ Previous studies have demonstrated that $\mathrm{Cr}$ is one of the effective alloying elements for improving the oxidation resistance of $\mathrm{Nb}$ silicides and $\mathrm{Nb}$ based alloys. ${ }^{8,9)}$ Therefore in this study, the focus was placed on the effect of $\mathrm{Cr}$ addition on the oxidation behavior of $\mathrm{NbSi}_{2}$ and the phase equilibria in the $\mathrm{Nb}-\mathrm{Cr}-\mathrm{Si}$ ternary system.

\section{Experimental Procedures}

Alloys were prepared by an arc-melting furnace using high purity raw materials $(\mathrm{Nb}$ : $3 \mathrm{~N}, \mathrm{Cr}: 4 \mathrm{~N}, \mathrm{Si}: 5 \mathrm{~N})$ under an $\mathrm{Ar}$ atmosphere. The base alloy composition was $\mathrm{Nb}-66.7$ mol\% Si, and $\mathrm{Cr}$ addition was made to substitute the $\mathrm{Nb}$

\footnotetext{
${ }^{* 1}$ Corresponding author, E-mail: sekido@material.tohoku.ac.jp

${ }^{* 2}$ Graduate Student, Nihon University
}

atoms under the fixed $\mathrm{Si}$ content. Hereafter all the alloy compositions are given in mole percent. Seven alloys were prepared in this study: $\mathrm{Nb}-66.7 \mathrm{Si}, \mathrm{Nb}-3.3 \mathrm{Cr}-66.7 \mathrm{Si}, \mathrm{Nb}-$ 8.3Cr-66.7Si, $\mathrm{Nb}-16.7 \mathrm{Cr}-66.6 \mathrm{Si}, \mathrm{Nb}-25 \mathrm{Cr}-66.7 \mathrm{Si}, \mathrm{Nb}-$ $30 \mathrm{Cr}-66.7 \mathrm{Si}$, and $\mathrm{Cr}-66.7 \mathrm{Si}$. These alloys are denoted by their atomic fraction with the subscripts to the right of each atom; e.g., " $\mathrm{Nb}_{25} \mathrm{Cr}_{8.3} \mathrm{Si}_{66.7}$ " for the $\mathrm{Nb}-8.3 \mathrm{~mol} \% \mathrm{Cr}-$ $66.7 \mathrm{~mol} \% \mathrm{Si}$ alloy. Since the arc-melted ingots contained significant amounts of cracks and cavities, they were milled into powders, sieved under $25 \mu \mathrm{m}$, and consolidated again by spark plasma sintering (SPS) at $1200^{\circ} \mathrm{C}$ for 5 minutes under the applied pressure of $50 \mathrm{MPa}$. The SPS'ed samples were annealed at $1300^{\circ} \mathrm{C}$ for $50 \mathrm{~h}$ under vacuum. Microstructures were characterized by scanning electron microscopy (SEM). Phase identification was done by X-ray diffractometry (XRD) and energy dispersive X-ray spectrometry (EDS). Rietveld refinement was performed with the RIETAN software. ${ }^{10)}$ The melting temperatures of the alloys were determined by differential thermal analysis (DTA) using alumina crucibles in an Ar-flowing atmosphere. Oxidation behavior was examined by cyclic oxidation tests in air at 800, 1000, 1100 and $1200^{\circ} \mathrm{C}$. The dimensions of the oxidation test specimens are $3 \times 3 \times 3 \mathrm{~mm}^{3}$. The specimens were placed in alumina crucibles during cyclic oxidation tests, and the weight change by each cycle was measured as the samples being stayed in the crucibles.

\section{Results and Discussion}

\subsection{Microstructure and phase equilibria}

Figure 1 shows SEM micrographs of as-cast alloys: (a) $\mathrm{Nb}_{25} \mathrm{Cr}_{8.3} \mathrm{Si}_{66.7}$, (b) $\mathrm{Nb}_{16.7} \mathrm{Cr}_{16.7} \mathrm{Si}_{66.6}$, and (c) $\mathrm{Nb}_{8.3} \mathrm{Cr}_{25} \mathrm{Si}_{66.7}$ alloys. In accordance with the previous reports, $\left.{ }^{11,12}\right) \mathrm{NbSi}_{2}$ and $\mathrm{CrSi}_{2}$ exhibit separate ranges of homogeneities in the $\mathrm{Nb}-\mathrm{Cr}-\mathrm{Si}$ ternary system, although they both possess the same crystal structure of $\mathrm{C} 40\left(h P 9, P 6_{2} 22\right) .{ }^{13)}$ The primary solidification phase of the alloys shown in Fig. 1 is $\mathrm{NbSi}_{2}$ with brighter contrast, and $\mathrm{CrSi}_{2}$ forms subsequently to enclose the primary phase. This indicates that a peritectic type reaction is present in the $\mathrm{NbSi}_{2}-\mathrm{CrSi}_{2}$ pseudo-binary. 

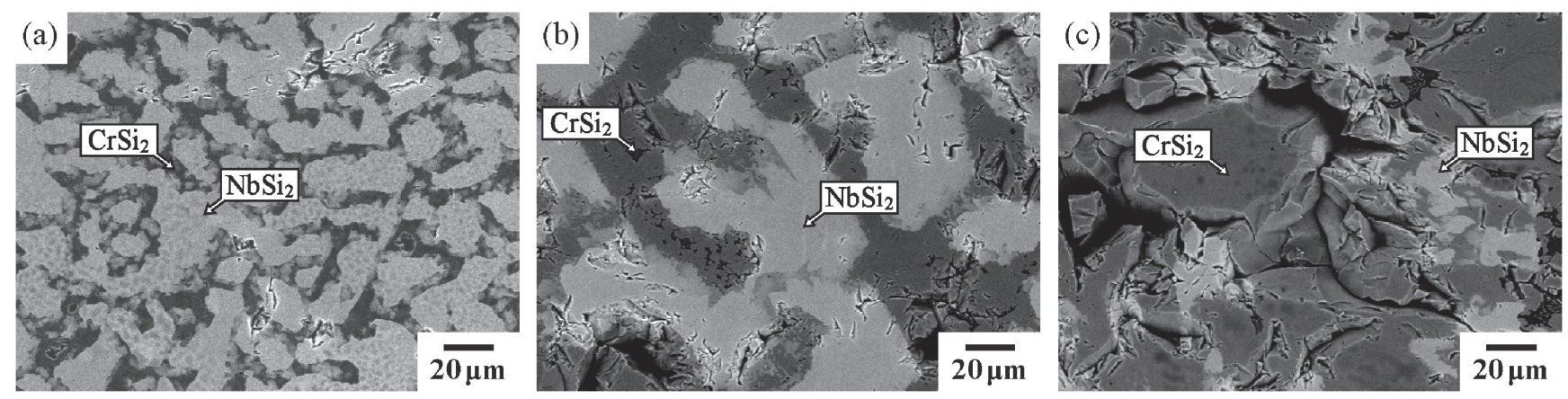

Fig. 1 SEM-BSE micrographs of as-cast alloys: (a) $\mathrm{Nb}_{25} \mathrm{Cr}_{8.3} \mathrm{Si}_{66.7}$, (b) $\mathrm{Nb}_{16.7} \mathrm{Cr}_{16.7} \mathrm{Si}_{66.6}$, and (c) $\mathrm{Nb}_{8.3} \mathrm{Cr}_{25} \mathrm{Si}_{66.7}$ alloys.
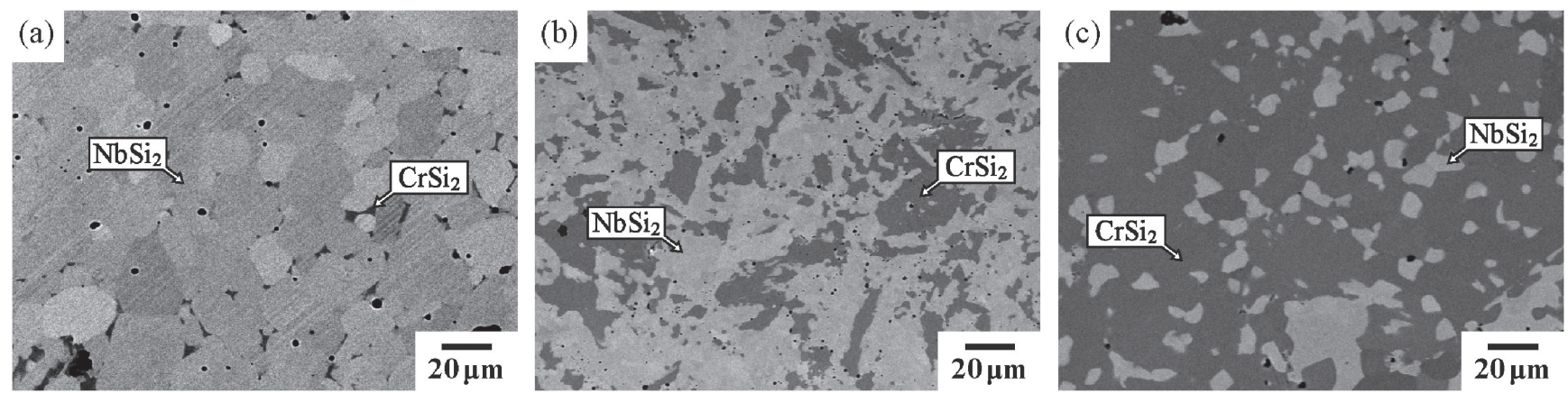

Fig. 2 SEM-BSE micrographs of the alloys SPS'ed and annealed at $1300^{\circ} \mathrm{C}$ for $50 \mathrm{~h}$ : (a) $\mathrm{Nb}_{25} \mathrm{Cr}_{8.3} \mathrm{Si}_{66.7},\left(\right.$ b) $\mathrm{Nb}_{16.7} \mathrm{Cr}_{16.7} \mathrm{Si}_{66.6}$, and (c) $\mathrm{Nb}_{8.3} \mathrm{Cr}_{25} \mathrm{Si}_{66.7}$ alloys.

Since the as-cast ingots contained a significant amount of shrinkage cavities and microcracks as shown in Fig. 1, they were milled into powder and consolidated again by SPS, which is followed by annealing at $1300^{\circ} \mathrm{C}$ for $50 \mathrm{~h}$. Figure 2 shows SEM micrographs of the alloys after the annealing. Although some small cavities are visible on the micrographs, sound specimens without any microcracks have been obtained after SPS and annealing. These alloys exhibit twophase microstructures comprised of $\mathrm{NbSi}_{2}$ and $\mathrm{CrSi}_{2}$, and the volume fraction of $\mathrm{CrSi}_{2}$ increases with increasing $\mathrm{Cr}$ content. Image analysis on the SEM micrographs has revealed that the volume fraction of $\mathrm{CrSi}_{2}$ is $3 \%$ in the $\mathrm{Nb}_{25} \mathrm{Cr}_{8.3} \mathrm{Si}_{66.7}$ alloy, while $75 \%$ in the $\mathrm{Nb}_{8.3} \mathrm{Cr}_{25} \mathrm{Si}_{66.7}$ alloy. The compositions of $\mathrm{NbSi}_{2}$ and $\mathrm{CrSi}_{2}$ phases were analyzed
Table 1 Summary of EDS results analized in the $\mathrm{Nb}_{16.7} \mathrm{Cr}_{16.7} \mathrm{Si}_{66.6}$ alloy annealed at $1300^{\circ} \mathrm{C}$.

\begin{tabular}{cccc}
\hline \multirow{2}{*}{ Phase } & \multicolumn{3}{c}{ Composition (mol\%) } \\
& $\mathrm{Nb}$ & $\mathrm{Cr}$ & $\mathrm{Si}$ \\
\hline \hline $\mathrm{NbSi}_{2}$ & $23.3 \pm 0.9$ & $10.0 \pm 1.6$ & $66.7 \pm 1.9$ \\
$\mathrm{CrSi}_{2}$ & $3.5 \pm 0.7$ & $30.9 \pm 2.9$ & $65.6 \pm 2.8$ \\
\hline
\end{tabular}

by EDS, of which results are summarized in Table 1 . The range of homogeneity for $\mathrm{NbSi}_{2}$ is comparatively larger than that for $\mathrm{CrSi}_{2}$ in the ternary system.

Figure 3 shows a result of Rietveld refinement on the annealed $\mathrm{Nb}_{16.7} \mathrm{Cr}_{16.7} \mathrm{Si}_{66.6}$, alloy. Upon Rietveld refinement,

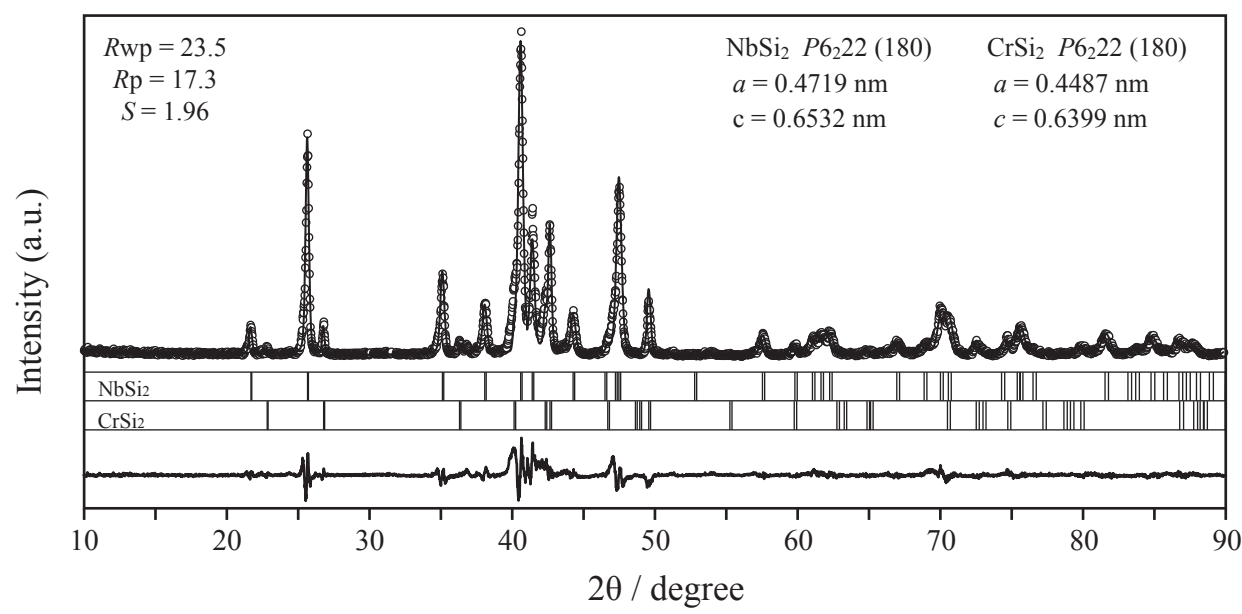

Fig. 3 A result of Rietveld refinement on the annealed $\mathrm{Nb}_{16.7} \mathrm{Cr}_{16.7} \mathrm{Si}_{66.6}$, alloy. The refined structure parameters are summarized in Table 2. 
Table 2 The structure parameters $\mathrm{NbSi}_{2}$ and $\mathrm{CrSi}_{2}$ refined the Rietveld method.

\begin{tabular}{cccccccc}
\hline Phase & Site & Wyck. & $g$ & $x$ & $y$ & $z$ & $U\left(\AA^{2}\right)$ \\
\hline \hline \multirow{2}{*}{$\mathrm{CrSi}_{2}$} & $\mathrm{Si} 1$ & $6 i$ & 1 & 0.1658 & 0.3316 & 0 & 0.0100 \\
& $\mathrm{Cr} 1$ & $3 c$ & 0.97 & $1 / 2$ & 0 & 0 & 0.0096 \\
& $\mathrm{Nb} 1$ & $3 c$ & $=1-g(\mathrm{Cr} 1)$ & $=x(\mathrm{Cr} 1)$ & $=y(\mathrm{Cr} 1)$ & $=z(\mathrm{Cr} 1)$ & $=U(\mathrm{Cr} 1)$ \\
\hline \multirow{2}{*}{$\mathrm{NbSi}_{2}$} & $\mathrm{Si} 2$ & $6 i$ & 1 & 0.1658 & 0.3316 & 0 & 0.0076 \\
& $\mathrm{Nb} 2$ & $3 c$ & 0.69 & $1 / 2$ & 0 & 0 & 0.0039 \\
& $\mathrm{Cr} 2$ & $3 c$ & $=1-g(\mathrm{Nb} 2)$ & $=x(\mathrm{Nb} 2)$ & $=y(\mathrm{Nb} 2)$ & $=z(\mathrm{Nb} 2)$ & $=U(\mathrm{Nb} 2)$ \\
\hline
\end{tabular}

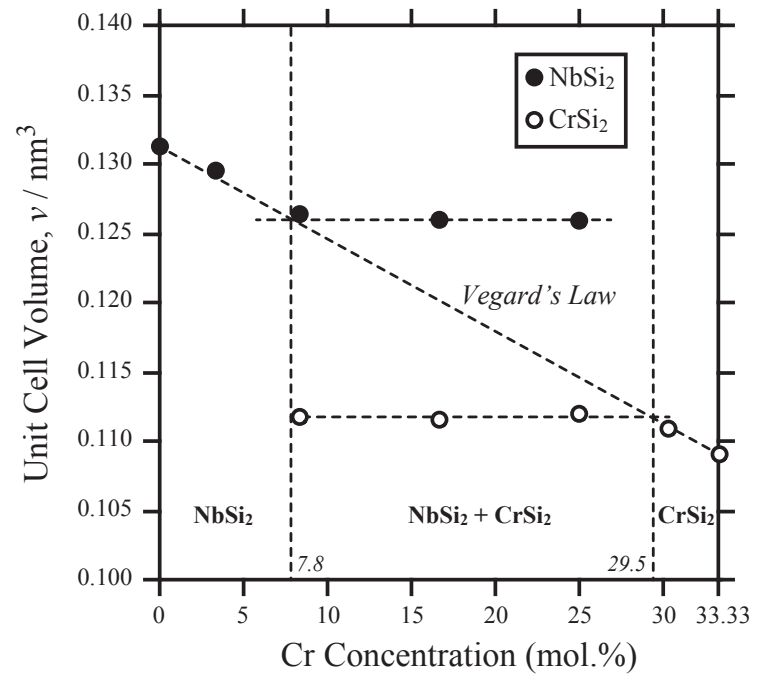

Fig. 4 Variation in the unit cell volume against $\mathrm{Cr}$ concentration.

no substitutional defects were assumed to occur on the $\mathrm{Si}$ sites of both $\mathrm{NbSi}_{2}$ and $\mathrm{CrSi}_{2}$, and the atom positions were fixed to the reported coordinates of the binary compounds. ${ }^{13)}$ Table 2 summarizes the structure parameters for $\mathrm{NbSi}_{2}$ and $\mathrm{CrSi}_{2}$ that have been refined in this study. The occupancy of $\mathrm{Cr}$ at the $\mathrm{Cr} 1$ site of $\mathrm{CrSi}_{2}$ is 0.97 , while that of $\mathrm{Nb}$ at the $\mathrm{Nb} 2$ site of $\mathrm{NbSi}_{2}$ is 0.69 . This means that the expected composition of the $\mathrm{CrSi}_{2}$ phase is $C_{\mathrm{Nb}}=1.0, C_{\mathrm{Cr}}=32.3$, $C_{\mathrm{Si}}=66.7$ in the mole percent, and that of the $\mathrm{NbSi}_{2}$ phase is $C_{\mathrm{Nb}}=23.0, C_{\mathrm{Cr}}=10.3, C_{\mathrm{Si}}=66.7$. These values reasonably agree with those obtained by EDS summarized in Table 1.

Figure 4 represents a change in the unit cell volume against the $\mathrm{Cr}$ concentration. Here the unit cell volume, $v$, is defined by the following equation,

$$
v=a^{2} c \sin \frac{2 \pi}{3}
$$

where $a$ and $c$ are the lattice parameters of $\mathrm{NbSi}_{2}$ and $\mathrm{CrSi}_{2}$ determined by the Rietveld refinements. The unit cell volume decreases with $\mathrm{Cr}$ content, and it becomes constant within the range of compositions, where two phases of $\mathrm{NbSi}_{2}$ and $\mathrm{CrSi}_{2}$ are in equilibrium. The phase boundaries were defined by the intersections between the straight line by the Vegard's law and the line within the two phase region, as shown in Fig. 4. The determined phase boundary concentrations of $\mathrm{Cr}$ are 7.8 and 29.5. These values reasonably agree with with those determined by EDS.

The melting temperatures of the alloys were determined by DTA. Figure 5 shows DTA profiles for (a) $\mathrm{Nb}_{16.7} \mathrm{Cr}_{16.7} \mathrm{Si}_{66.6}$,

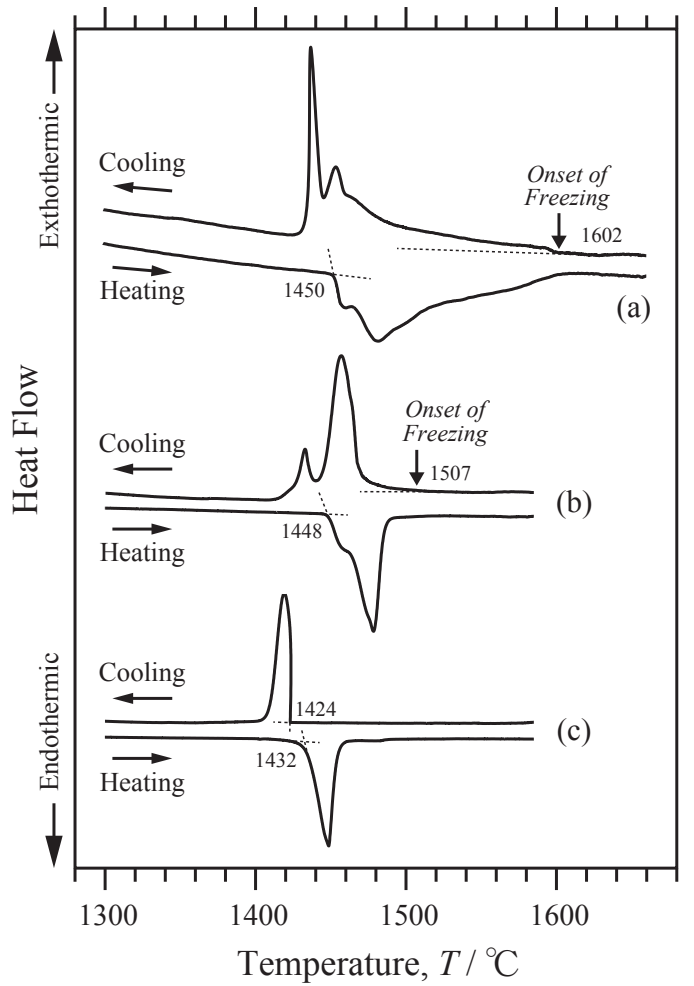

Fig. 5 Experimental DTA profiles for (a) $\mathrm{Nb}_{16.7} \mathrm{Cr}_{16.7} \mathrm{Si}_{66.6}$, (b) $\mathrm{Nb}_{8.3} \mathrm{Cr}_{25} \mathrm{Si}_{66.7}$ and (c) $\mathrm{Cr}_{33.3} \mathrm{Si}_{66.7}$ alloys.

(b) $\mathrm{Nb}_{8.3} \mathrm{Cr}_{25} \mathrm{Si}_{66.7}$ and (c) $\mathrm{Cr}_{33.3} \mathrm{Si}_{66.7}$ alloys. $\mathrm{Cr}_{33.3} \mathrm{Si}_{66.7}$ alloys is a binary $\mathrm{CrSi}_{2}$ single-phase alloy that exhibits congruent melting, ${ }^{14)}$ and therefore the profile exhibits puremetal like behavior as in Fig. 5(c). By averaging the onset temperatures of melting and freezing, the melting temperature of $\mathrm{CrSi}_{2}$ is determined to be $1428^{\circ} \mathrm{C}$, which is slightly lower than the reported temperature of $1439^{\circ} \mathrm{C} .{ }^{14)}$ On the other hand, $\mathrm{Nb}_{16.7} \mathrm{Cr}_{16.7} \mathrm{Si}_{66.6}$ and $\mathrm{Nb}_{8.3} \mathrm{Cr}_{25} \mathrm{Si}_{66.7}$ alloys exhibit a solid-solution like freezing behavior, showing less-distinct onsets upon freezing. In such cases, it has been pointed out that good results are often obtained by defining the deviation point from the base line to be the onset of freezing. ${ }^{15)}$ Therefore in this study, the onset of freezing is defined from the point, at which the signals start to deviate from the base lines, as in Fig. 5(a) and (b).

Based on the results of EDS, XRD and DTA, coupled with microstructural observations, the vertical section that connects between the $\mathrm{NbSi}_{2}$ and $\mathrm{CrSi}_{2}$ binary edges was determined as shown in Fig. 6. The melting temperature of $\mathrm{NbSi}_{2}$ was adopted from the literature. ${ }^{16)}$ It is found that the 


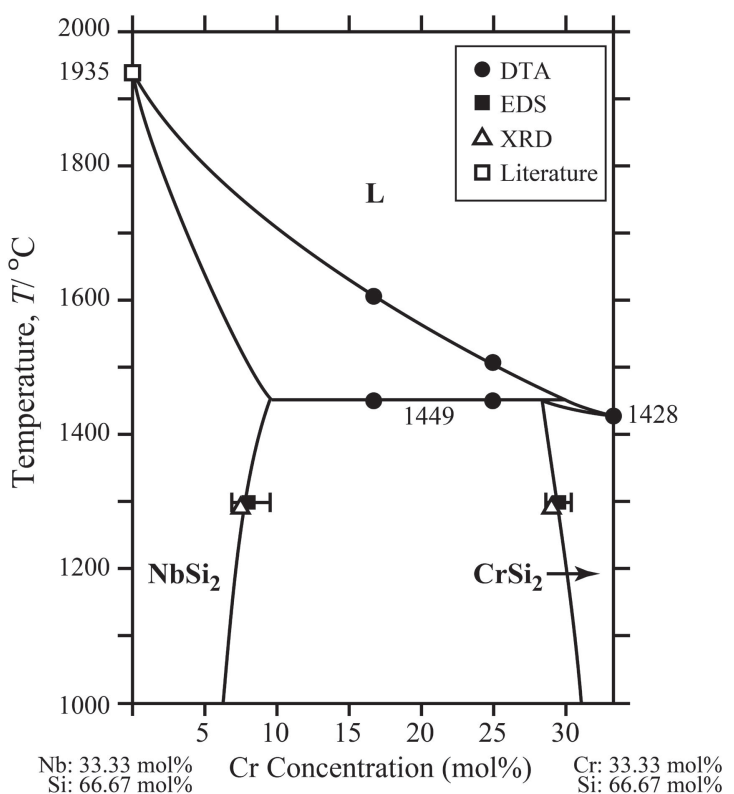

Fig. 6 The vertical section between $\mathrm{NbSi}_{2}$ and $\mathrm{CrSi}_{2}$ in the $\mathrm{Nb}-\mathrm{Cr}-\mathrm{Si}$ ternary system.

range of homogeneity for $\mathrm{NbSi}_{2}$ at $1300^{\circ} \mathrm{C}$ is larger than at $1000^{\circ} \mathrm{C}$ previously reported. ${ }^{11,12)}$ On the other hand, $\mathrm{Nb}$ substitutional defects that can develop at the $\mathrm{Cr}$ site of $\mathrm{CrSi}_{2}$ are smaller than those reported by Goldschmidt et al., ${ }^{11)}$ but comparable to those by Zhao et al. ${ }^{12)}$

\subsection{Oxidation behavior}

Oxidation behavior of the alloys was studied by cyclic oxidation tests in air at $800,1000,1100$, and $1200^{\circ} \mathrm{C}$. For oxidation tests, the specimens were put in a furnace heated to the test temperatures, kept for a set time, and removed from the furnace, which was followed by weight change measurements by measuring the weight of crucibles as the samples being stayed. Therefore in this study, small disintegration or spalling of oxide products will not result in weight loss. Series of these procedures were repeated with the keeping duration of $10 \mathrm{~h}$ up to the cumulative time of $100 \mathrm{~h}$, and the keeping duration of $20 \mathrm{~h}$ up to the cumulative time of $500 \mathrm{~h}$.

Figures 7 and 8 summarize the appearances of the specimens tested at $1000^{\circ} \mathrm{C}$ and $1200^{\circ} \mathrm{C}$ for the representative cumulative oxidation times. The $\mathrm{Nb}_{33.3} \mathrm{Si}_{66.7}$ alloy (i.e., binary $\mathrm{NbSi}_{2}$ alloy) exhibited pest-like behavior both at 1000 and $1200^{\circ} \mathrm{C}$, where oxidized products had disintegrated and swelled inside the crucibles. Figure 9 shows an XRD profile obtained from the disintegrated powder of the $\mathrm{Nb}_{33.3} \mathrm{Si}_{66.7}$ alloy oxidized at $1000^{\circ} \mathrm{C}$. The oxide products are mainly composed of two niobium pentaoxides, $\gamma-\mathrm{Nb}_{2} \mathrm{O}_{5}\left(\mathrm{~T}-\mathrm{Nb}_{2} \mathrm{O}_{5}\right.$, JCPDS \#27-1312) and $\beta-\mathrm{Nb}_{2} \mathrm{O}_{5}$ (JCPDS \#26-0885). This is consistent with the previous reports, where the formation of $\mathrm{Nb}_{2} \mathrm{O}_{5}$ is responsible for pest-like behavior due to its porous and non-protective character., ${ }^{7}, 17$

Although the binary $\mathrm{NbSi}_{2}$ compound did not show any protective oxidation behavior, $\mathrm{Cr}$ addition to $\mathrm{NbSi}_{2}$ was found to improve the oxidation resistance drastically. At $1000^{\circ} \mathrm{C}$, all the $\mathrm{Cr}$-containing alloys exhibited no spalling or disintegration after oxidation up to $500 \mathrm{~h}$. The surfaces of the samples have tarnished into a greenish color, implying that $\mathrm{Cr}_{2} \mathrm{O}_{3}$ could have formed on the surface. On the other hand, after cyclic oxidation at $1200^{\circ} \mathrm{C}$ for $500 \mathrm{~h}$, the $\mathrm{Nb}_{16.7} \mathrm{Cr}_{16.7} \mathrm{Si}_{66.6}$ and $\mathrm{Nb}_{8.3} \mathrm{Cr}_{25} \mathrm{Si}_{66.7}$ alloys exhibited dis-

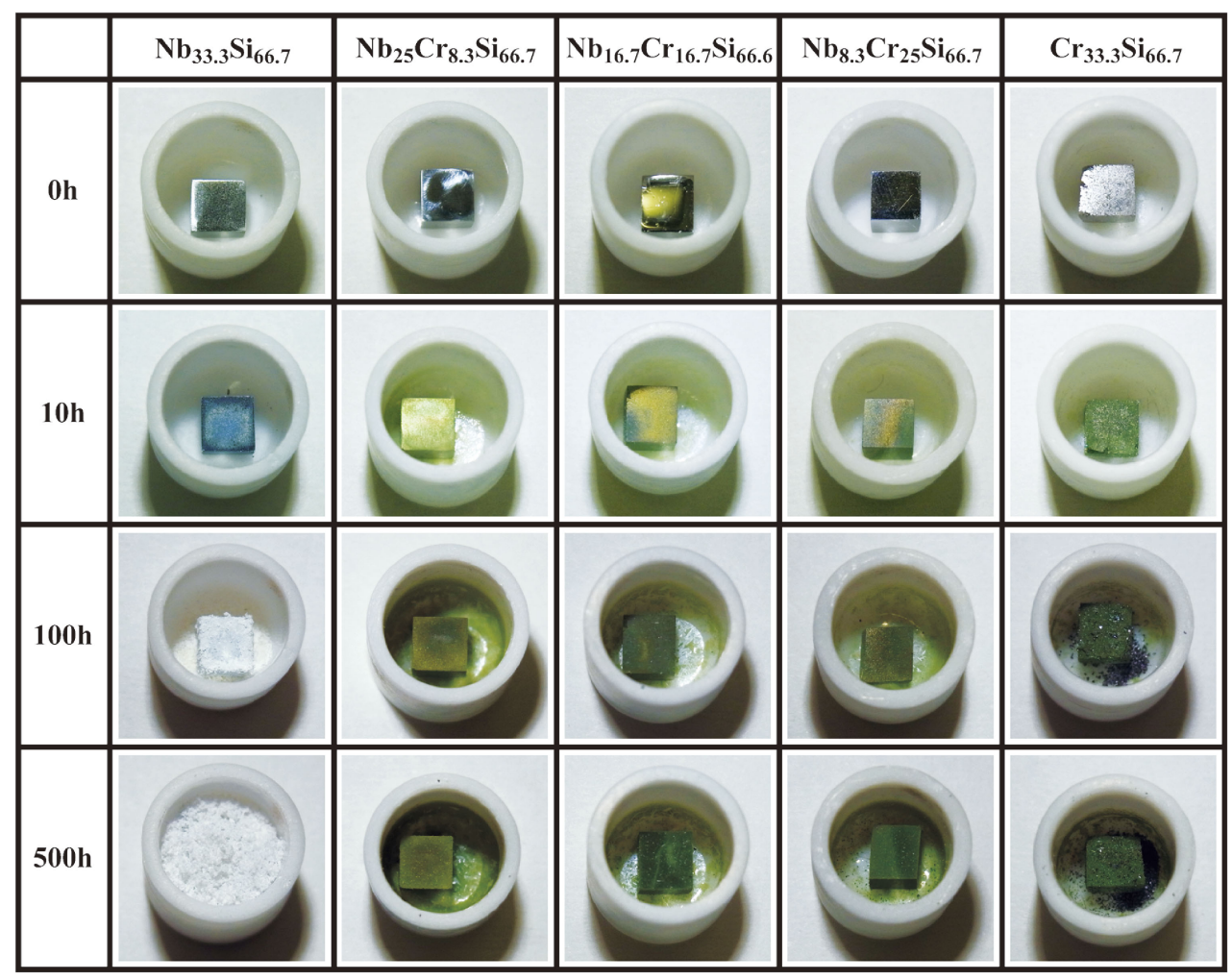

Fig. 7 Change of the appearances of oxidation test specimens tested at $1000^{\circ} \mathrm{C}$ for various cumulative oxidation durations. Cubic specimens were placed in alumina crucibles. 


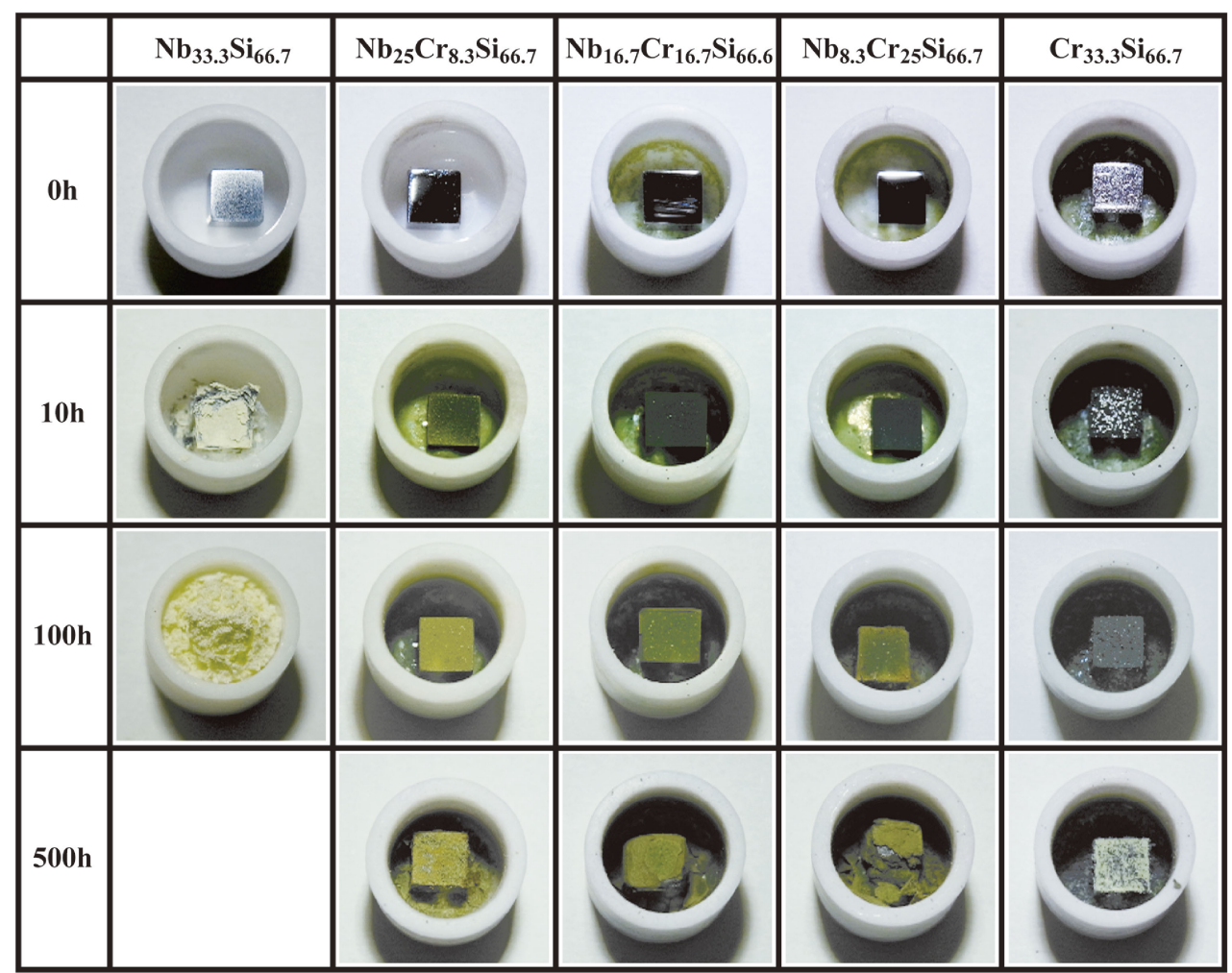

Fig. 8 Change of the appearances of oxidation test specimens tested at $1200^{\circ} \mathrm{C}$ for various cumulative oxidation durations. Cubic specimens were placed in alumina crucibles.

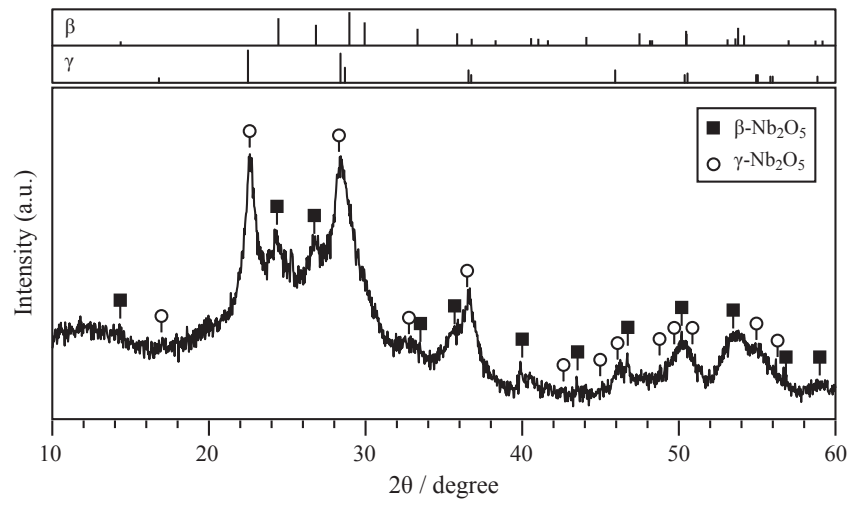

Fig. 9 An XRD profile of the disintegrated powder of the $\mathrm{Nb}_{33.3} \mathrm{Si}_{66.7}$ alloy oxidized at $1000^{\circ} \mathrm{C}$.

integrations at the edges of the specimens, as shown in Fig. 8. The detailed mechanism of the disintegration is unclear, but speculated that a $\mathrm{NbSi}_{2} / \mathrm{CrSi}_{2}$ two-phase microstructure is susceptible to spalling of the oxide scales due to the difference in the oxidation characteristics of the two. Note that the $\mathrm{Cr}_{33.3} \mathrm{Si}_{66.7}$ alloy is a $\mathrm{CrSi}_{2}$ single-phase alloy, and the $\mathrm{Nb}_{25} \mathrm{Cr}_{8.3} \mathrm{Si}_{66.7}$ alloy is nearly single-phase of $\mathrm{NbSi}_{2}$, of which the volume fraction is $97 \%$.

Figure 10 shows the weight change per unit surface area at (a) $800^{\circ} \mathrm{C}$, (b) $1000^{\circ} \mathrm{C}$, (c) $1100^{\circ} \mathrm{C}$, and (d) $1200^{\circ} \mathrm{C}$ upon cyclic oxidation. Note that the results of the $\mathrm{Nb}_{33.3} \mathrm{Si}_{66.7}$ alloy (i.e., binary $\mathrm{NbSi}_{2}$ alloy) were not included in Fig. 10, because it exhibited sever pesting behavior so that the weight change could not be measured accurately. As shown in Fig. 10(a), all the alloys exhibited gradual weight gains with elapsed oxidation time at $800^{\circ} \mathrm{C}$. At $1000^{\circ} \mathrm{C}$
(Fig. 10(b)), the $\mathrm{Cr}_{33.3} \mathrm{Si}_{66.7}$ alloy showed a relatively large weight gain, however the other ternary alloys, $\mathrm{Nb}_{25} \mathrm{Cr}_{8.3} \mathrm{Si}_{66.7}, \mathrm{Nb}_{16.7} \mathrm{Cr}_{16.7} \mathrm{Si}_{66.6}$ and $\mathrm{Nb}_{8.3} \mathrm{Cr}_{25} \mathrm{Si}_{66.7}$, exhibited less-significant weight changes at this temperature. If diffusion of oxygen through a growing oxide scale were the rate determining process for the weight gains, the parabolic rate constant, $k_{\mathrm{p}}$, for $\mathrm{Nb}_{25} \mathrm{Cr}_{8.3} \mathrm{Si}_{66.7}$ at $1000^{\circ} \mathrm{C}$ can be evaluated to be: $k_{\mathrm{p}}=5.8 \times 10^{-8}\left(\mathrm{mg}^{2} / \mathrm{cm}^{4} / \mathrm{s}\right)$, which is three orders of magnitude smaller than that for some commercial Ni-based superalloys at the same temperature. ${ }^{18)}$ At $1100^{\circ} \mathrm{C}$ (Fig. 10(c)), the $\mathrm{Cr}_{33.3} \mathrm{Si}_{66.7}$ alloy exhibited more pronounced weight gains, while the other alloys exhibited small weight change during oxidation up to $500 \mathrm{~h}$. On the contrary, the weight gain of the $\mathrm{Cr}_{33.3} \mathrm{Si}_{66.7}$ alloy at $1200^{\circ} \mathrm{C}$ appears to be lower than that at $1100^{\circ} \mathrm{C}$. It is reported that $\mathrm{Cr}_{2} \mathrm{O}_{3}$ sublimates at temperatures above $1000^{\circ} \mathrm{C}$ through the following reaction: ${ }^{19,20)} \mathrm{Cr}_{2} \mathrm{O}_{3}(\mathrm{~s})+3 / 2 \mathrm{O}_{2} \rightarrow 2 \mathrm{CrO}_{3}(\mathrm{~g})$. Therefore, this was caused by sublimation of $\mathrm{Cr}_{2} \mathrm{O}_{3}$ that became more significant at $1200^{\circ} \mathrm{C}$ than at $1100^{\circ} \mathrm{C}$. At the same time, the $\mathrm{Nb}_{16.7} \mathrm{Cr}_{16.7} \mathrm{Si}_{66.6}$ and $\mathrm{Nb}_{8.3} \mathrm{Cr}_{25} \mathrm{Si}_{66.7}$ alloys showed considerable fluctuation in the weight change. This behavior would be associated with the disintegrations of the specimens upon cyclic oxidation, as depicted in Fig. 8. In this context, the $\mathrm{Nb}_{25} \mathrm{Cr}_{8.3} \mathrm{Si}_{66.7}$ alloy showed the highest oxidation resistance up to $1200^{\circ} \mathrm{C}$, because the amount of weight change is the smallest, and the disintegration of the specimen is minimal.

To identify the oxides that form on the surface during oxidation tests, the samples were milled into rough powder, and oxidized in air at $1200^{\circ} \mathrm{C}$ for $50 \mathrm{~h}$. Figures 11 and 12 show XRD profiles obtained from the oxidized powders of $\mathrm{Nb}_{25} \mathrm{Cr}_{8.3} \mathrm{Si}_{66.7}$ and $\mathrm{Cr}_{33.3} \mathrm{Si}_{66.7}$, respectively. For the $\mathrm{Nb}_{25} \mathrm{Cr}_{8.3} \mathrm{Si}_{66.7}$ alloy shown in Fig. $11, \mathrm{NbCrO}_{4}, \mathrm{Cr}_{2} \mathrm{O}_{3}$, and 
(a)

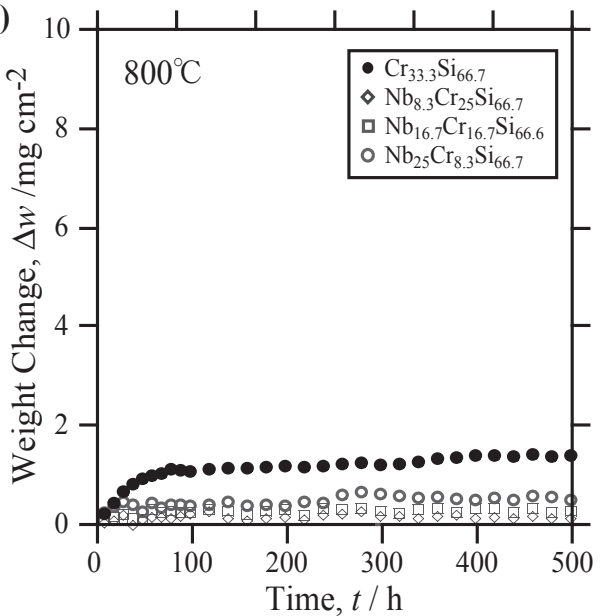

(c)

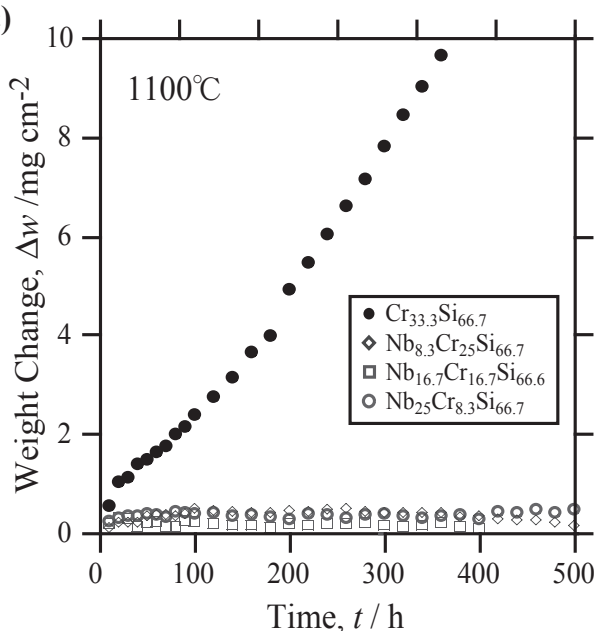

(b)

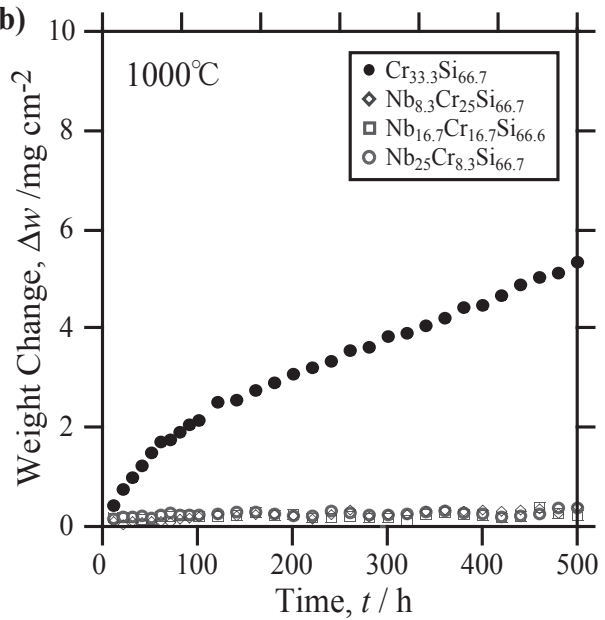

(d)

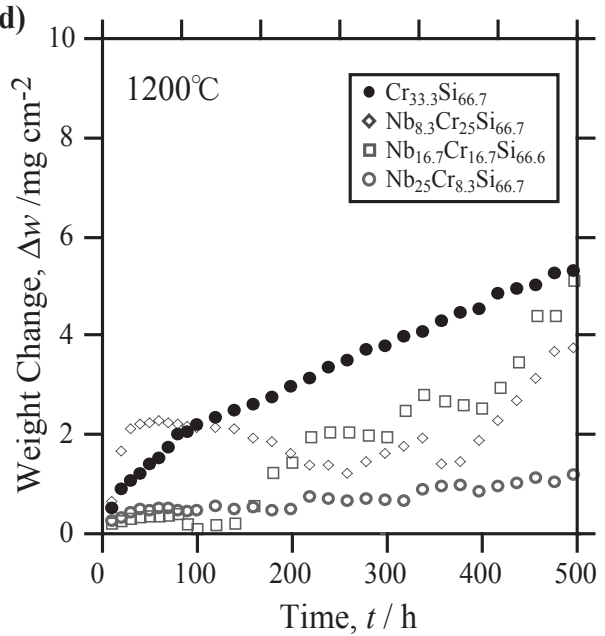

Fig. 10 Weight change by cyclic oxidation tested at (a) $800^{\circ} \mathrm{C}$, (b) $1000^{\circ} \mathrm{C}$, (c) $1100^{\circ} \mathrm{C}$, and (d) $1200^{\circ} \mathrm{C}$.

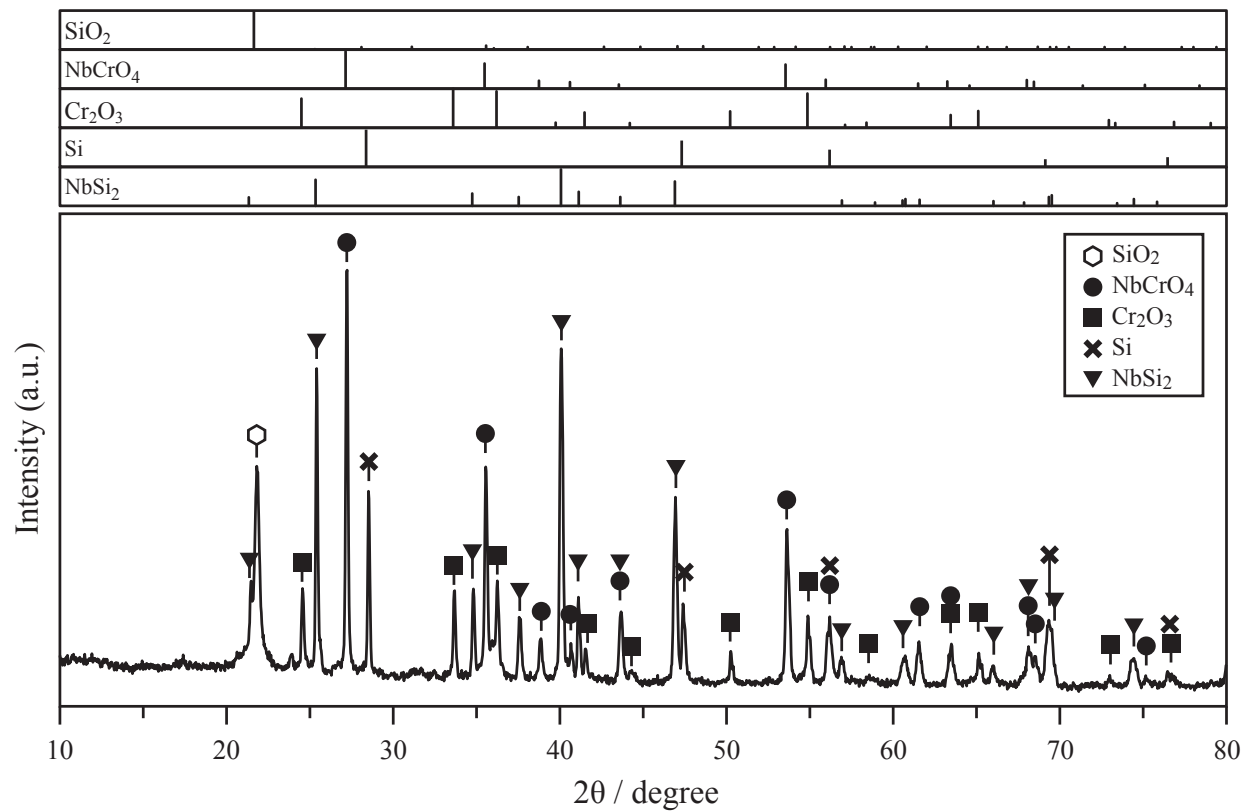

Fig. 11 An XRD profile of the $\mathrm{Nb}_{25} \mathrm{Cr}_{8.3} \mathrm{Si}_{66.7}$ alloy oxidized in air at $1200^{\circ} \mathrm{C}$ for $50 \mathrm{~h}$.

$\mathrm{Si}$ are indicated to have formed after oxidation at $1200^{\circ} \mathrm{C}$, while formation of $\mathrm{Nb}_{2} \mathrm{O}_{5}$ is not confirmed. It has been pointed out that formation of $\mathrm{NbCrO}_{4}$ instead of $\mathrm{Nb}_{2} \mathrm{O}_{5}$ is beneficial for suppressing the pest-like behavior and thereby enhancing the oxidation resistance of $\mathrm{Nb}$ silicides. ${ }^{17,21)}$ Therefore, the significant improvement in the oxidation 


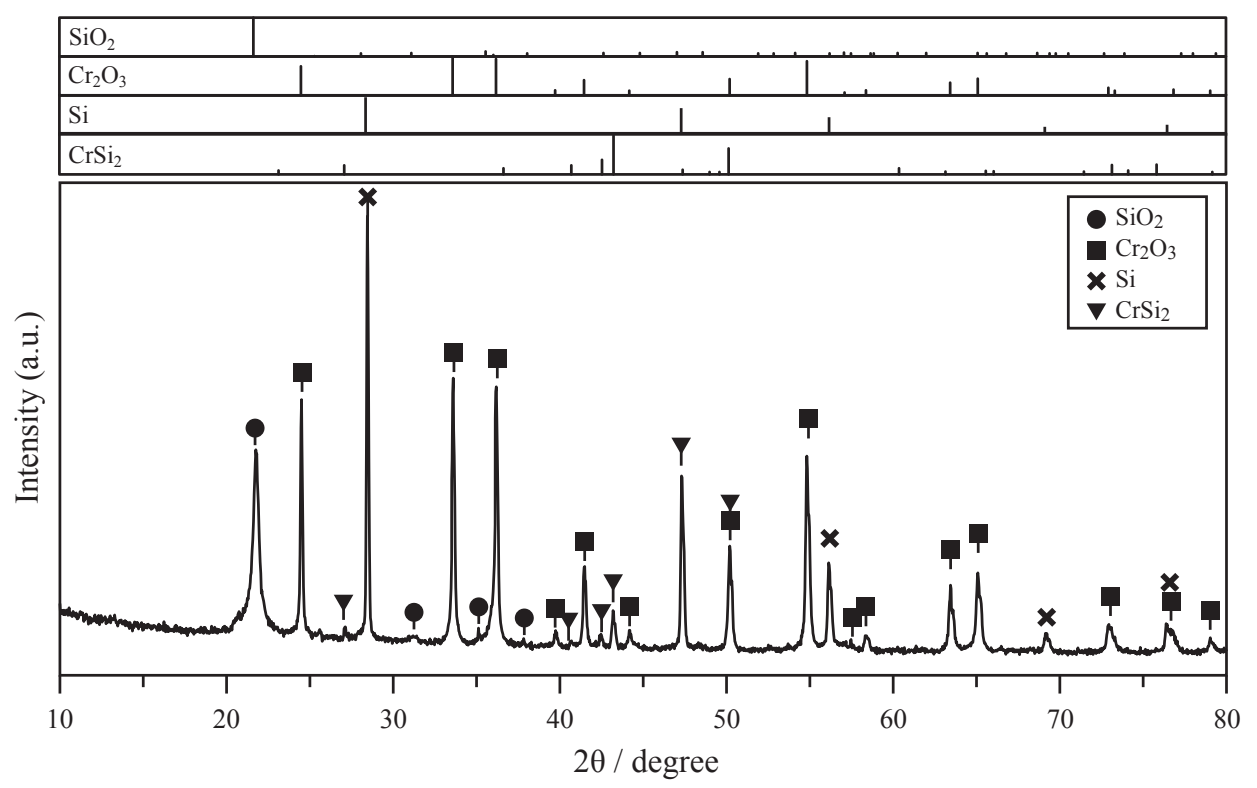

Fig. 12 An XRD profile of the $\mathrm{Cr}_{33.3} \mathrm{Si}_{66.7}$ alloy oxidized in air at $1200^{\circ} \mathrm{C}$ for $50 \mathrm{~h}$.
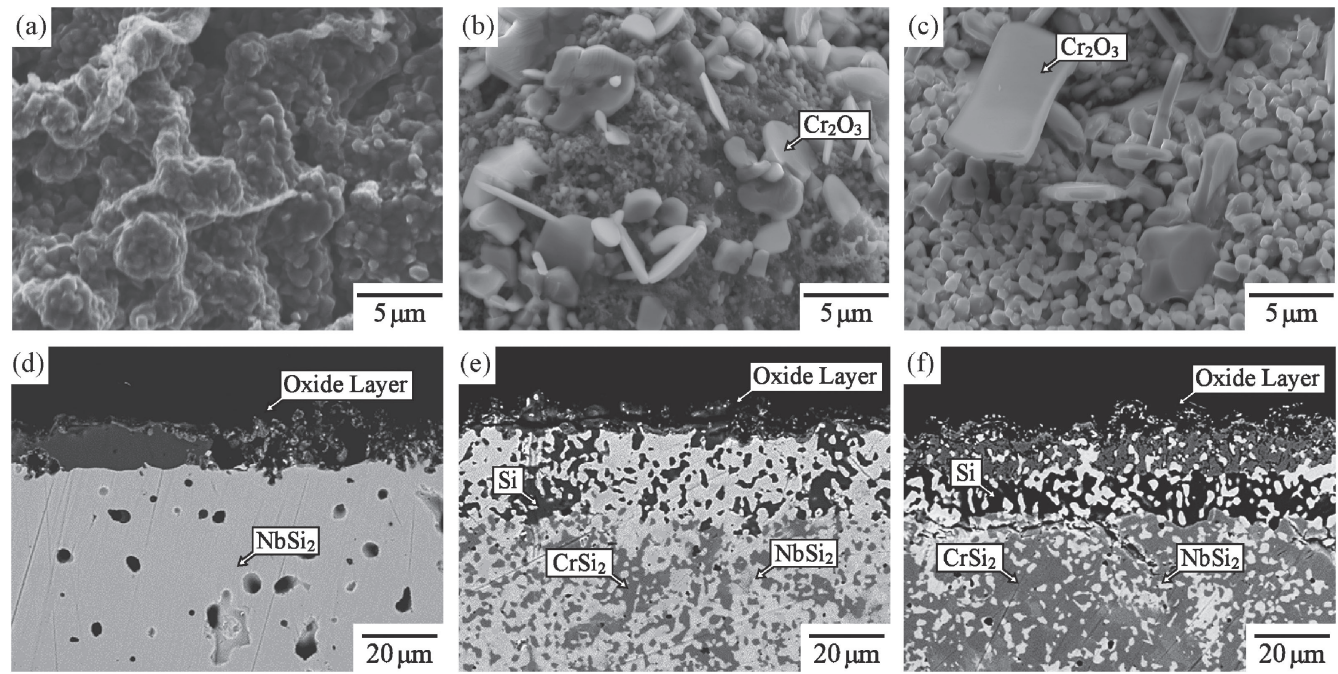

Fig. 13 SEM micrographs of the surfaces $(\mathrm{a}-\mathrm{c})$ and the cross sections $(\mathrm{d}-\mathrm{f})$ of the specimens oxidized at $1200^{\circ} \mathrm{C}$ for $50 \mathrm{~h}$. (a, d) $\mathrm{Nb}_{25} \mathrm{Cr}_{8.3} \mathrm{Si}_{66.7}$ (b, e) $\mathrm{Nb}_{16.7} \mathrm{Cr}_{16.7} \mathrm{Si}_{66.6}$, and (c, f) $\mathrm{Nb}_{8.3} \mathrm{Cr}_{25} \mathrm{Si}_{66.7}$.

resistance of $\mathrm{NbSi}_{2}$ by $\mathrm{Cr}$ additions would be attributed to the formation of $\mathrm{NbCrO}_{4}$, in addition to $\mathrm{Cr}_{2} \mathrm{O}_{3}$ formation. At the same time, formation of $\mathrm{Cr}_{2} \mathrm{O}_{3}$ and $\mathrm{Si}$ were indicated in $\mathrm{Cr}_{33.3} \mathrm{Si}_{66.7}$ from XRD profile as shown in Fig. 12. It should be noted that, for both $\mathrm{Nb}_{25} \mathrm{Cr}_{8.3} \mathrm{Si}_{66.7}$ and $\mathrm{Cr}_{33.3} \mathrm{Si}_{66.7}$ alloys, formation of crystalline $\mathrm{SiO}_{2}$ ( $\alpha$-cristobalite) during oxidation at $1200^{\circ} \mathrm{C}$ for $50 \mathrm{~h}$ was indicated in this study. It is well known that, for many silicides, amorphous $\mathrm{SiO}_{2}$ usually forms at the early stage of its formation, and crystallization of $\mathrm{SiO}_{2}$ gradually proceeds during exposure at temperatures higher than $1100^{\circ} \mathrm{C}^{7)}$ In fact, the formation of $\alpha$-cristobalite together with $\mathrm{Cr}_{2} \mathrm{O}_{3}$ has been confirmed in $\mathrm{Cr}-\mathrm{Mo}-\mathrm{Si}$ alloys for oxidation in the temperature range of $1000-1200^{\circ} \mathrm{C}$. ${ }^{22}$ ) It is therefore suggested that $\mathrm{SiO}_{2}$ also forms on the surfaces of the alloys, which contributes increased oxidation resistance.

Figure 13 shows SEM micrographs of the surfaces and the cross sections of the specimens oxidized at $1200^{\circ} \mathrm{C}$ for
50 h: (a, d) $\mathrm{Nb}_{25} \mathrm{Cr}_{8.3} \mathrm{Si}_{66.7}$ (b, e) $\mathrm{Nb}_{16.7} \mathrm{Cr}_{16.7} \mathrm{Si}_{66.6}$, and (c, f) $\mathrm{Nb}_{8.3} \mathrm{Cr}_{25} \mathrm{Si}_{66.7}$. The oxides on the surfaces showing thin-disk morphology are $\mathrm{Cr}_{2} \mathrm{O}_{3}$, which was confirmed by EDS. This suggests that $\mathrm{Cr}$ was preferentially oxidized to form $\mathrm{Cr}_{2} \mathrm{O}_{3}$ on the surface, which at the same time contributes to improve the oxidation resistance of $\mathrm{Nb}-\mathrm{Cr}-\mathrm{Si}$ ternary alloys, particularly at lower temperatures. The surface oxide layers are comprised of plural oxides, which is in agreement with the empirical knowledge: oxide scales comprised of $\mathrm{SiO}_{2}$ and metal-oxides tend to form in $\mathrm{NbSi}_{2}, \mathrm{TaSi}_{2}$ and $\mathrm{CrSi}_{2}$, of which oxygen affinity of the metallic element is close to that of $\mathrm{Si}^{23)}$ Cross sectional observations have clearly depicted the development of reaction layers beneath the surface oxide layers. The region with dark contrast in the reaction layer was identified to be the Si phase by EDS. This is consistent with the XRD results shown in Fig. 11, where the formation of $\mathrm{Si}$ was observed in the oxidized powder. The white phase adjacent to $\mathrm{Si}$ in the reaction layer is the $\mathrm{NbSi}_{2}$ phase, of 
which $\mathrm{Cr}$ content is lower than that inside. It is indicated that the formation of the $\mathrm{Si}$ phase occurs because outward diffusion of $\mathrm{Cr}$ occurs significantly due to $\mathrm{Cr}_{2} \mathrm{O}_{3}$ formation on the surface. At the same time, it is speculated that inward diffusion of oxygen leads to stabilization of the Si phase, since the three phase equilibrium of $\mathrm{NbSi}_{2} / \mathrm{SiO}_{2} / \mathrm{Si}$ is attained in the $\mathrm{Nb}-\mathrm{Si}-\mathrm{O}$ system, ${ }^{24,25)}$ and $\mathrm{CrSi}_{2} / \mathrm{SiO}_{2} / \mathrm{Si}$ in the $\mathrm{Cr}-\mathrm{Si}-\mathrm{O}$ ternary system. ${ }^{26}$ )

In this study, $\mathrm{Cr}$ addition to binary $\mathrm{NbSi}_{2}$ compounds was found to be effective to enhance the oxidation resistance drastically. This is primarily caused by the preferential formation of $\mathrm{NbCrO}_{4}$ and $\mathrm{Cr}_{2} \mathrm{O}_{3}$, by which the oxygen potential at the interface between the oxide scale and substrate is lowered to the dissociation pressure of $\mathrm{Nb}_{2} \mathrm{O}_{5}$ and thereby the formation of deleterious $\mathrm{Nb}_{2} \mathrm{O}_{5}$ is suppressed. However the amount of $\mathrm{Cr}$ addition should be limited within the homogeneity range of $\mathrm{NbSi}_{2}$, because $\mathrm{NbSi}_{2} / \mathrm{CrSi}_{2}$ two-phase alloys are susceptible to spalling and disintegration of the oxide scales upon cyclic oxidation. In addition, $\mathrm{Cr}_{2} \mathrm{O}_{3}$ can sublimate at $1100^{\circ} \mathrm{C}$ or higher, which results in degradation of the oxide scales developed on the substrates. In this context, the $\mathrm{Nb}_{25} \mathrm{Cr}_{8.3} \mathrm{Si}_{66.7}$ alloy, which has nearly a $\mathrm{NbSi}_{2}$ single-phase microstructure, showed the highest oxidation resistance at temperatures up to $1200^{\circ} \mathrm{C}$.

\section{Conclusions}

$\mathrm{NbSi}_{2}$ and $\mathrm{CrSi}_{2}$ are found to form separated ranges of homogeneities in the $\mathrm{Nb}-\mathrm{Cr}-\mathrm{Si}$ ternary system. The vertical section passing through the $\mathrm{NbSi}_{2}$ and $\mathrm{CrSi}_{2}$ binary edges (i.e., the isopleth at $66.67 \mathrm{~mol} \% \mathrm{Si}$ ) was experimentally determined in this study. The range of homogeneity of $\mathrm{NbSi}_{2}$ is found to be larger than that previously reported. A binary $\mathrm{NbSi}_{2}$ alloy exhibits poor oxidation resistance, showing pest-like behavior during oxidation at temperature between 800 and $1200^{\circ} \mathrm{C}$ due to the formation of $\mathrm{Nb}_{2} \mathrm{O}_{5}$. In contrast, $\mathrm{Nb}-\mathrm{Cr}-\mathrm{Si}$ ternary alloys show better oxidation resistance by forming $\mathrm{NbCrO}_{4}, \mathrm{Cr}_{2} \mathrm{O}_{3}$ and $\mathrm{SiO}_{2}$, which then suppresses the formation of a detrimental oxidation product of $\mathrm{Nb}_{2} \mathrm{O}_{5}$. However large $\mathrm{Cr}$ additions that exceed the solubility limit of $\mathrm{NbSi}_{2}$ should be avoided, because the alloys with $\mathrm{NbSi}_{2} / \mathrm{CrSi}_{2}$ two-phase microstructure were susceptible to spalling and disintegration of the oxide scales upon cyclic oxidation.

\section{Acknowledgments}

A part of this study is financially supported by KEIRIN, which is gratefully acknowledged.

\section{REFERENCES}

1) B.P. Bewlay, M.R. Jackson, J.C. Zhao, M.G. Mendiratta, J.J. Lewandowski and P.R. Subramanian: MRS Bull. 28 (2003) 646-653.

2) P.R. Subramanian, M.G. Mendiratta, D.M. Dimiduk and M.A. Stucke: Mater. Sci. Eng. A 239-240 (1997) 1-13.

3) N. Sekido, Y. Kimura, F.G. Wei, S. Miura and Y. Mishima: J. Alloys Compd. 425 (2006) 223-229.

4) N. Sekido, Y. Kimura, S. Miura and Y. Mishima: Mater. Sci. Eng. A 444 (2007) 51-57.

5) P.R. Subramanian, M.G. Mendiratta and D.M. Dimiduk: MRS Symp. Proc. 250 (1993) 491-502.

6) B.P. Bewlay, M.R. Jackson and H.A. Lipsitt: Metall. Mater. Trans. A 27 (1996) 3801-3808.

7) R. Mitra: Structural Intermetallics and Intermetallic Matrix Composites, (CRC Press, Boca Raton, 2015).

8) T. Murakami, S. Sasaki, K. Ichikawa and A. Kitahara: Intermetallics 9 (2001) 629-635.

9) B.P. Bewlay, M.R. Jackson, J.C. Zhao and P.R. Subramanian: Metall. Mater. Trans. A 34 (2003) 2043-2052.

10) F. Izumi and T. Ikeda: Mater. Sci. Forum 321-324 (2000) 198-205.

11) H.J. Goldschmidt and J.A. Brand: J. Less Common Met. 3 (1961) 34.

12) J.C. Zhao, M.R. Jackson and L.A. Peluso: Acta Mater. 51 (2003) 63956405.

13) P. Villars and K. Cenzual: Pearson's Crystal Data: Crystal Structure Database for Inorganic Compounds, (ASM International, Materials Park, Ohio, USA, 2007).

14) H. Okamoto: J. Phase Equilib. 22 (2001) 593.

15) W.J. Boettinger, U.R. Kattner, K.-W. Moon and J.H. Perepezko: DTA and Heat-flux DSC Measurements of Alloy Melting and Freezing, (NIST, Washington, 2006).

16) M.E. Schlesinger, H. Okamoto, A.B. Gokhale and R. Abbaschian: J. Phase Equilib. 14 (1993) 502-509.

17) S.K. Varma, C. Parga, K. Amato and J. Hernandez: J. Mater. Sci. 45 (2010) 3931-3937.

18) S. Cruchley, H. Evans and M. Taylor: Mater. High Temp. 33 (2016) $465-475$.

19) D. Caplan and M. Cohen: J. Electrochem. Soc. 108 (1961) 438-442.

20) H.C. Graham and H.H. Davis: J. Am. Ceram. Soc. 54 (1971) 89-93.

21) K.S. Chan: Metall. Mater. Trans. A 35 (2004) 589-597.

22) S.V. Raj: Mater. Sci. Eng. A 201 (1995) 229-241.

23) K. Kurokawa and A. Yamauchi: Solid State Phenom. 127 (2007) 227232.

24) E. Horache, J.E. Fischer and J. Van Der Spiegel: J. Appl. Phys. 68 (1990) 4652-4655.

25) D.L. Yaney and A. Joshi: J. Mater. Res. 5 (1990) 2197-2208.

26) H. Jiang, H.J. Whitlow, M. Östling, E. Niemi, F.M. d'Heurle and C.S. Petersson: J. Appl. Phys. 65 (1989) 567-574. 